\title{
Multidimensional structural variation in the cyanotrichite family of merotypes
}

\author{
Stuart James Mills ${ }^{1}$, Andrew Christy ${ }^{2}$, Georges Favreau ${ }^{3}$ \\ ${ }^{1}$ Museum Victoria, Melbourne, Australia, ${ }^{2}$ School of Earth Sciences, University of Queensland, St Lucia, Australia, ${ }^{3} \mathrm{~N} / \mathrm{A}$, Aix-en- \\ Provence, France \\ E-mail: smills@museum.vic.gov.au
}

The acicular blue minerals of the cyanotrichite group have been known for more than two centuries. However, their crystals are usually very thin, deformed and mosaiced, so their structural and chemical complexities are only just being elucidated, thanks to synchrotron XRD from micron-scale regions of good crystal quality.

Structures in the cyanotrichite group share a $[\mathrm{Cu} 2 \mathrm{Al}(\mathrm{OH}) 6]+$ ribbon of edge-sharing $\mathrm{Cu}$ and $\mathrm{Al}$ polyhedra $\| \mathrm{b}$ of a (pseudo)monoclinic subcell. The ribbons lie en echelon in layers II (001), while between these layers, SO42- tetrahedra, [AIF4(H2O)2]- or [Sb(OH)6]- octahedra and $\mathrm{H} 2 \mathrm{O}$ molecules form rods also II b. Ideal formulae can be written as $2[\mathrm{Cu} 2 \mathrm{Al}(\mathrm{OH}) 6]++[\mathrm{SO} 4] 2-+2(\mathrm{H} 2 \mathrm{O})$ for cyanotrichite, $3[\mathrm{Cu} 2 \mathrm{Al}(\mathrm{OH}) 6]++[\mathrm{Sb}(\mathrm{OH}) 6]-+[\mathrm{SO} 4] 2-+2(\mathrm{H} 2 \mathrm{O})$ for camerolaite, and $4[\mathrm{Cu} 2 \mathrm{Al}(\mathrm{OH}) 6]++[\mathrm{Al} 2 \mathrm{~F} 6(\mathrm{H} 2 \mathrm{O}) 4] 0+4 \mathrm{OH}$ - for khaidarkanite.

The average cyanotrichite structure has $b \sim 2.9 \AA$, defined by the width of one (Cu,Al)X6 octahedron along a ribbon. However, the structure is an intergrowth of an invariant 'host' module (layers of $\mathrm{Cu}-\mathrm{Al}$ ribbons) with rod-like 'guest' modules whose periodicity is necessarily a multiple of that of the host. Thus, rods may be offset relative to their neighbours in a variety of ways. Coupling between the rods is usually short-range, resulting in diffuse X-ray scattering only. The first structure refined was that of khaidarkanite [1]. Although the periodicity along any given fluoraluminate rod must be 4b [2], the structure showed no long-range order, and the unit cell $\left(\mathrm{C} 2 / \mathrm{m}, \mathrm{a}=12.326 \AA, b=2.907 \AA, c=10.369 \AA, \beta=97.90^{\circ}\right)$ is typical of the average structure for the group. Loss of C-centering in some specimens and a wide range of $\beta$ angles $92-$ $99^{\circ}$ [1], suggested that structural variation occurs without significant change in cell dimensions, due to (i) offset of ribbons $\| \mathrm{b}$ in the xy plane; (ii) offset of layers $\| \mathrm{a}$ in the xy plane; and (iii) shear of ribbons in the xz plane. Symmetry-lowering distortions were characterised in refinements of the triclinic C-1 structure of a camerolaite crystal [2] and of the P2/m structure of one of the two cyanotrichite crystals refined in [3] (the other was $\mathrm{C} 2 / \mathrm{m}$ ).

Crystals of both cyanotrichite and camerolaite from the Cap Garonne mine (France) gave sharp superstructure reflections. In the case of $\mathrm{P} 2 / \mathrm{m}$ cyanotrichite, a $4 \mathrm{~b}$ superstructure was observed, consistent with the sequence of species [-SO4-SO4$(\mathrm{H} 2 \mathrm{O}) 2-(\mathrm{H} 2 \mathrm{O}) 2-]$ along any given rod, but the data was not good enough to refine. However, a single crystal of camerolaite has yielded superstructure peaks sharp enough for refinement, confirming that the $3 \mathrm{~b}$ superstructure arises from alternation of $\mathrm{Sb}(\mathrm{OH}) 6$ and $\mathrm{SO} 4$ along $b$. For the first time, we observe a large systematic offset from one $\mathrm{Sb}$ to the next along the $c$ direction $(\sim 0.4 \mathrm{~b})$, which means that the most nearly orthogonal cell is actually F-centred triclinic with a doubled $c$ repeat and doubled volume $(F-1, a=12.472 \AA, b=8.758=3 \times 2.919 \AA, c=21.478=2 \times 10.739 \AA, a=85.930, \beta=$ 95.900, $\left.\mathrm{Y}=92.35^{\circ}\right)$.

[1] Hager, S. et al. (2009) Can. Mineral., 47, 635-648.

[2] Mills, S.J., et al. (2014) Mineral. Mag., 78, 1527-1552.

[3] Mills, S.J., et al. (2015) Mineral. Mag., 79, 321-336.

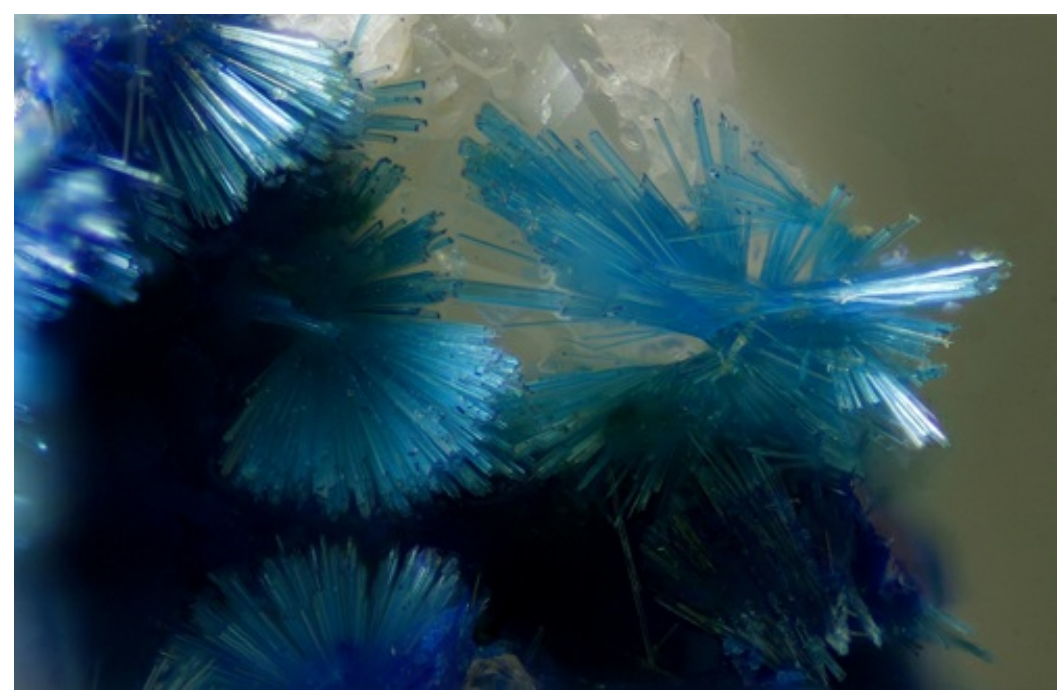

Keywords: cyanotrichite, camerolaite, merotype 